\title{
Design, Scaling, and Development of Biofilters with E crassipes for Treatment of Water Contaminated with Cr (VI)
}

\author{
Uriel Fernando Carreño Sayago
}

check for updates

Citation: Carreño Sayago, U.F. Design, Scaling, and Development of Biofilters with E crassipes for Treatment of Water Contaminated with Cr (VI). Water 2021, 13, 1317. https://doi.org/10.3390/w13091317

Academic Editor: Alicia

Ronda Gálvez

Received: 10 March 2021

Accepted: 27 April 2021

Published: 8 May 2021

Publisher's Note: MDPI stays neutral with regard to jurisdictional claims in published maps and institutional affiliations.

Copyright: (C) 2021 by the author. Licensee MDPI, Basel, Switzerland. This article is an open access article distributed under the terms and conditions of the Creative Commons Attribution (CC BY) license (https:/ / creativecommons.org/licenses/by/ $4.0 /)$.
Facultad de Ingeniería, Fundación Universitaria los Libertadores, 111221 Bogotá, Colombia; ufcarrenos@libertadores.edu.co

\begin{abstract}
The heavy metal water treatment process is the subject of worldwide research. Chromium (VI) is a heavy metal that is very dangerous to humans due to it being able to alter genetic material and cause cancer. Cellulose is an interesting material for removing heavy metals, and excellent removals have been achieved in many experiments at the laboratory scale. However, scaling these processes to polluting industries is not easy. The objective of this research is to design, scale, and test a biofilter with biomass of $\mathrm{E}$ crassipes transformed with iron for treatment of water contaminated with $\mathrm{Cr}$ (VI). The biomasses of E crassipes (EC) and E crassipes with iron (EC + Fe) were evaluated at the batch laboratory scale to determine the adsorption capacities through Langmuir isotherms. With these capacities, a mass balance was formulated, obtaining the design equation to build a biofilter at the pilot scale and providing the required amount of biomass from (EC) and (EC $+\mathrm{Fe})$ for the adequate treatment of the $\mathrm{Cr}(\mathrm{VI})$ present in the water. The mass, as suggested by the relevant equations, for the greatest concentration of $\mathrm{Cr}(\mathrm{VI})$ of $500 \mathrm{mg} / \mathrm{L}$ was $42 \mathrm{~g}$ together with a flow rate of $10 \mathrm{~mL} / \mathrm{min}$ for the biomass of $(\mathrm{EC}+\mathrm{Fe})$; for the biomass of $(\mathrm{EC})$, the suggested model for the treatment of the greatest $\mathrm{Cr}(\mathrm{VI})$ concentration of $500 \mathrm{mg} / \mathrm{L}$ was $64 \mathrm{~g}$ of biomass together with a flow rate of $10 \mathrm{~mL} / \mathrm{min}$. We conclude that the two pilot-scale treatment systems were consistent with the $\mathrm{Cr}(\mathrm{VI})$ removal process and that the equation for the design was adequate.
\end{abstract}

Keywords: models; E crassipes; biofilter; chromium (VI)

\section{Introduction}

Water care has become a necessity in environmental policies throughout the world due to the evident deterioration of rivers, lagoons, wetlands, etc. One of the many ways in which our planet's water is being negatively affected is through the outrageous pollution from industries.

Water decontamination is a fundamental goal in sustainable development policies, and due to this, new effective and cheap treatment systems must be researched, designed and developed for the proper care of this valuable resource [1].

Heavy metals are a clear contaminant of water resources. Metals such as mercury, chromium, and nickel, among others, cause serious damage to aquatic ecosystems as well as to human health [2]. Hexavalent chromium (Cr) (VI) is highly carcinogenic as it has the capacity to alter genetic material; due to this, care must be taken in the treatment of water contaminated with this heavy metal [3-6].

However, the conventional treatment of water is very expensive and difficult to carry out - for example, activated sludge, oxidation ditches, and membrane filtration, among others [7].

Biological filters with a static adsorbent material are an alternative for the adequate effective treatment of water contaminated with heavy metals, due to the efficiency, easy assembly, and cheapness of this treatment [8].

The adsorbent material that makes up biofilters can be the cellulose prevenient of waste material, as this biomass has multiple available sites $\left(\mathrm{OH}, \mathrm{CH}_{2}, \mathrm{COOH}\right)$ where heavy metals can house in chemical diffusion processes [9-11]. 
A native, invasive, and high-impact plant is Eichhornia crassipes; due to its high reproduction rate, it can overpopulate a wetland in just a few months from its arrival in the microsystem [12,13].

Currently, this biomass of E crassipes (EC) is wasted due to the lack of sustainability policies for its management. Additionally, owing to the high amount of cellulose, it could be used for the design and assembly of cheap and effective treatment systems to treat water contaminated with $\mathrm{Cr}$ (VI) from the tannery industry, as in, for example, [13-17].

To optimize the treatment process with the biomass of the (EC) plant, it can be treated with iron chloride; this chemical compound oxidizes the organic matter, creating more active sites and increasing the chemical affinity with heavy metals [18-21].

Tests to determine the removal efficiencies of heavy metals through biomass have been carried out at the batch laboratory scale where adsorption capacities and kinetics of adsorption were obtained [22-26].

Subsequently, these tests could be validated through pilot-scale tests, such as fixed column adsorption assessments, in an arrangement akin to that which is used to treat the effluents of industries [27].

In [28-30], the authors experimented on batch, determining the design parameters and scaling the results by developing fixed columns for the treatment of heavy metals with biochar. The mass balances were used to determine the amount of pollutant load that must be treated, thus achieving the discharge aims [31].

The objective of this research is to design, scale, and evaluate a biofilter with a biomass of (EC) transformed with iron for treatment of water contaminated with $\mathrm{Cr}$ (VI). Through the development of a biotreatment in batch, the adsorption capacities of $\mathrm{Cr}$ (VI) by (EC) and $(\mathrm{EC}+\mathrm{Fe})$ can be determined. With these capacities, a balance of mass was formulated, resulting in the equation of design of a build biofilter at the pilot scale; the removal efficiency of $\mathrm{Cr}(\mathrm{VI})$ was subsequently evaluated by part of the biofilter.

Until now, in the literature, biofilters with these characteristics have not been seen. Although the (EC) plant was using for the adsorption of $\mathrm{Cr}$ (VI) and $\mathrm{Pb}$ (II) in continuous processes [18,27], these design parameters of the treatment systems were not established. Therefore, the novelty of this study is the implementation of the balance of mass, which provides an equation to determine design variables in the construction of a continuous filter with biomass of (EC) and (EC $+\mathrm{Fe})$.

\section{Materials and Methods}

\subsection{Use of (EC)}

The E crassipes plants were collected in a wetland in the Mosquera municipality on the outskirts of Bogotá D.C, and were then washed (EC) with distilled water, separating the root from the stem and the leaves. They were dried at $70{ }^{\circ} \mathrm{C}$ for $48 \mathrm{~h}$ to remove moisture and grind to a diameter of $0.212 \mathrm{~mm}$. The pulverized biomass was sieved through a knife mill to get different sizes of particles.

\subsection{Obtaining Cellulose Modified with Iron}

Biomass with iron chloride was mixed with $1 \mathrm{~g}$ of cellulose (EC) and $200 \mathrm{~mL}$ of deionized water; then, $1 \mathrm{~g}$ of iron chloride with a $\mathrm{pH}$ of 3.0 was added. Then, the suspension was placed in a shaker for $3 \mathrm{~h}$ at $175 \mathrm{rpm}$ and $50{ }^{\circ} \mathrm{C}$ to impregnate Fe (III) into the surface of the cellulose [23].

Then, the $\mathrm{pH}$ of the suspension was adjusted to 10.0 to form $\mathrm{FeOOH}$ on the cellulose surface using $40 \mathrm{mg} / \mathrm{L} \mathrm{NaOH}$. Finally, the cellulose loaded with iron was obtained by drying in an oven for $3 \mathrm{~h}$ at $60^{\circ} \mathrm{C}$. With this process $(\mathrm{EC}+\mathrm{Fe})$, was created.

\subsection{Chromium Measurement}

Cr (VI) laboratory measurement: 50, 100, 200 and 300 mg/L of Cr (VI). Samples were taken in the flask at each time interval, and the residual chromium concentration was analyzed. Then, $20 \mu \mathrm{m}$ samples were taken and then placed in the centrifuge (KASAI MIKRO 200, 
Hettich, Föhrenstr Germany). In sampling, aliquots of the reaction mixture were analyzed for residual chromium concentration using a (UV84 Hettich, Föhrenstr Germany).

\subsection{Batch Adsorption Experiment}

Batch adsorption experiments were carried out in a $100 \mathrm{~mL}$ glass vessel with constant stirring (IKA Ks 4000 shaker, Hettich, Föhrenstr Germany) at $20^{\circ} \mathrm{C}, 150 \mathrm{rpm}$. Data were recorded every $20 \mathrm{~min}$ for $180 \mathrm{~min}$. The sample taken was $20 \mu \mathrm{m}$. All experiments were carried out in triplicate, with an average of the final values.

Spectrophotometer (Evolution 300 spectrophotometer, Hettich, Föhrenstr Germany) by monitoring changes in absorbance. All procedures for the determination of chromium, for water and substrates, were carried out using the APHA (Procedure of the American Public Health Association) for standard tests (standard methods for the examination of water and wastewater).

The $1000 \mathrm{mg} / \mathrm{L} \mathrm{Cr}$ (VI) stock solution was prepared with distilled water using potassium dichromate. This stock solution was used to prepare the test solutions of 50, 100, 200 and $300 \mathrm{mg} / \mathrm{L} \mathrm{Cr}(\mathrm{VI})$. The batch adsorption study was carried out at room temperature. The adsorption capacity was determined by suspending $0.3 \mathrm{~g}$ of biomass in $40 \mathrm{~mL}$ of $\mathrm{Cr}$ (VI) test solution for $140 \mathrm{~min}$ at $200 \mathrm{rpm}$, taking samples every $20 \mathrm{~min}$ and centrifuging at $15,000 \mathrm{rpm}$ before determining the residue and discarding the sediment.

\subsection{Continuous Experimentation}

Depending on the capabilities presented in the batch experiment, the experimental design was developed to quantify the transformed biomass, volume, fluxes, and other design parameters of a biofilter.

\section{Results}

\subsection{Mass Balance Process}

In Figure 1, the representative scheme of the biological biofilter composed of material of $(\mathrm{EC})$ and $(\mathrm{EC}+\mathrm{Fe})$ is shown. For the purposes of balance, the accumulation of polluting material in the biomass will be taken into account, as represented by Equation (1).

$$
\text { Acumulation }=\text { Input }- \text { output }- \text { chemisorption }
$$

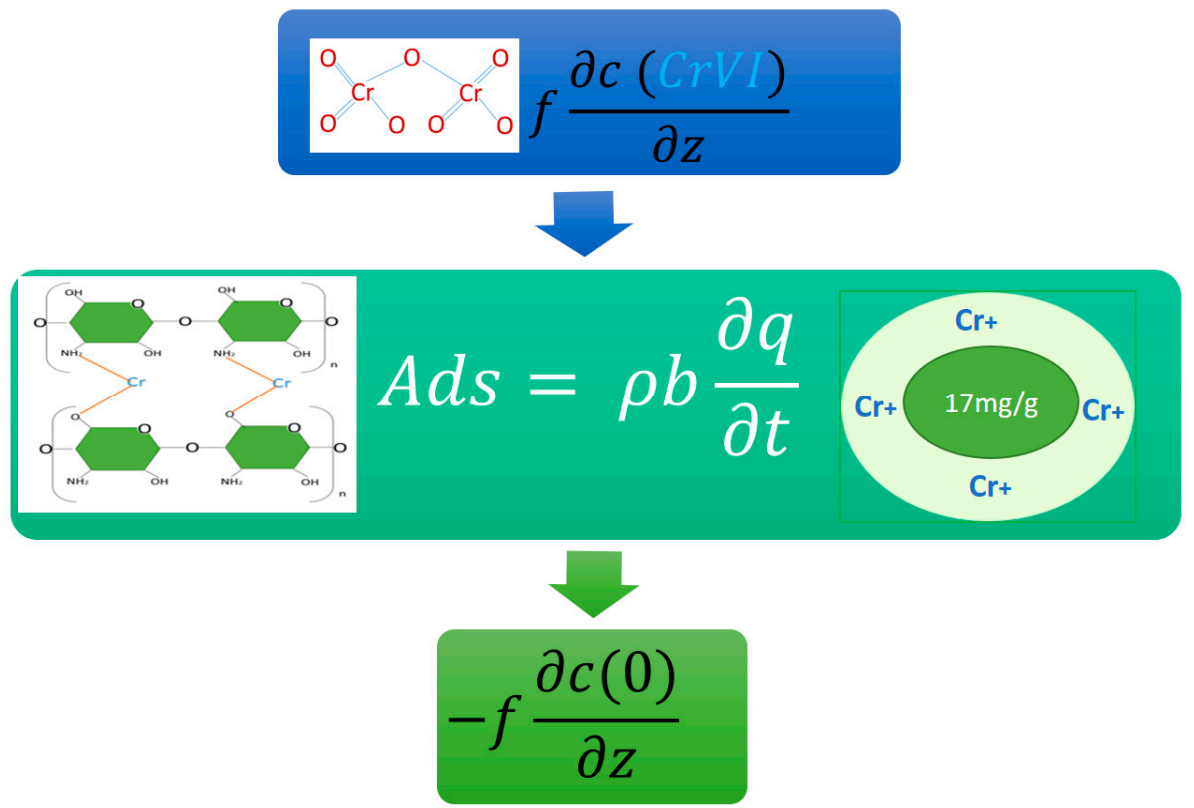

Figure 1. Representation of the filter model in the $\mathrm{Cr}(\mathrm{VI})$ treatment process-mathematical model of input, output and internal adsorption. 
Each of these will be explained through differential equations, since changes $(\partial)$ occur over time in capacity $(\partial q)$, concentration $(\partial c)$ and porosity $(\partial \varepsilon)$.

The input to the biofilter is related to the flow velocity $(f)$, the initial $\mathrm{Cr}(\mathrm{VI})$ concentration in the treatment process and section of experimentation of biomass in the horizon longitudinal $(z)$ of the biofilter.

$$
\text { Input }=f C r(t, z)=f V \frac{\partial c(t, z)}{\partial z}
$$

The output of the biofilter is related to the flow rate $(f)$ and the final $\mathrm{Cr}(\mathrm{VI})$ concentration in the treatment process. Equation (3) assumes that the concentration end of $\mathrm{Cr}(\mathrm{VI})$ is (0).

$$
\text { Output }=f C r(t, z)=-f V \frac{\partial c(t, z)}{\partial z}
$$

In Equation (4), which is representing in the process of adsorption of the Cr (VI) contaminating material, it can be seen the change in the adsorption capacity $(q)$ is given as a function of time and space within the filter. The particle density $(p)$ and the total volume $(V)$ of the water to be treated also play important roles.

$$
\text { chemisorption }=\rho A r d z \frac{\partial q}{\partial t}=\rho V \frac{\partial q}{\partial t}
$$

The accumulation represents the porosity of the biofilter $(\varepsilon)$; this is the relationship between the particle density and the density of the filter medium and is represented by the following equation (Equation (5)).

$$
\text { Accumulation }=\varepsilon V \frac{\partial c}{\partial t}
$$

Equation (1) can give Equation (6), the general mass balance equation in the reactor that filters the water contaminated with heavy metals.

$$
\varepsilon \frac{\partial c}{\partial t}=f \frac{\partial c}{\partial z}-\rho \frac{\partial q}{\partial t}
$$

In Equation (6), the flow is considered $\mathrm{f}=\frac{\partial z}{\partial t}$.

$$
\varepsilon \frac{\partial c}{\partial t}=\frac{\partial c}{\partial t}-\rho \frac{\partial q}{\partial t}
$$

In the initial treatment process, it could be said that all these design parameters are constant, leaving Equation (8).

$$
m \frac{\partial q}{\partial t}=v \frac{\partial c}{\partial t}-\varepsilon v \frac{\partial c}{\partial t}
$$

where the time ( $T$ ) will be that of the rupture of the process, leaving Equation (9).

$$
m q=Q \operatorname{CoT}-\operatorname{Co\varepsilon } V
$$

When clearing $(m)$, Equation (10) remains.

$$
m=\frac{Q \operatorname{CoT}}{q}-\frac{\operatorname{Cos} V}{q}
$$

where $Q$ is the flow rate used $(\mathrm{ml} / \mathrm{min}), C_{0}$ is the initial Cr (VI) concentration of the process $\mathrm{mg} / \mathrm{L},(V)$ is the volume, and $(\varepsilon)$ is represented in [31,32]; relating the density of the particle and the density of the bed, together with the stipulated breakthrough curve $(T)$, the parameter measured in batch will be $(q)$, the adsorption capacity for the two biomasses. 
Through Equation (10), the biomass necessary to build a biofilter was determined in order to guarantee the removal of $\mathrm{Cr}(\mathrm{VI})$.

\subsection{Batch Experimentation}

Next, the experiments carried out in batch are presented in order to find the parameter of the capacity of biomass to adsorb $\mathrm{Cr}$ (VI). Figures 2 and 3 show two adsorption processes, where four types of the initial concentration of $\mathrm{Cr}(\mathrm{VI})$ are used, evaluating only the biomass of (EC) in the case of Figure 2; Figure 3 shows the removal percentages by part of $(\mathrm{EC}+\mathrm{Fe})$.

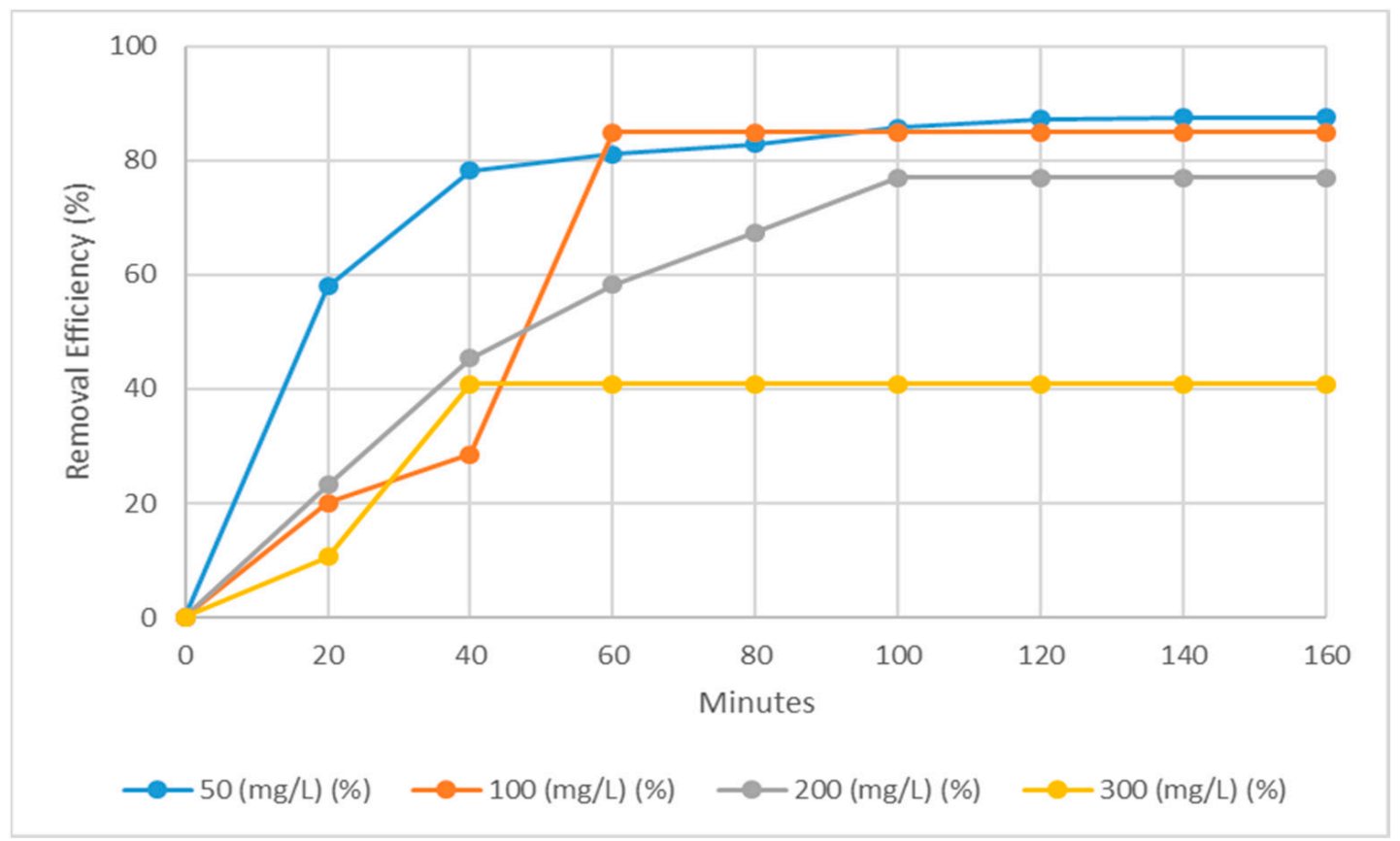

Figure 2. (EC) removal percentages.

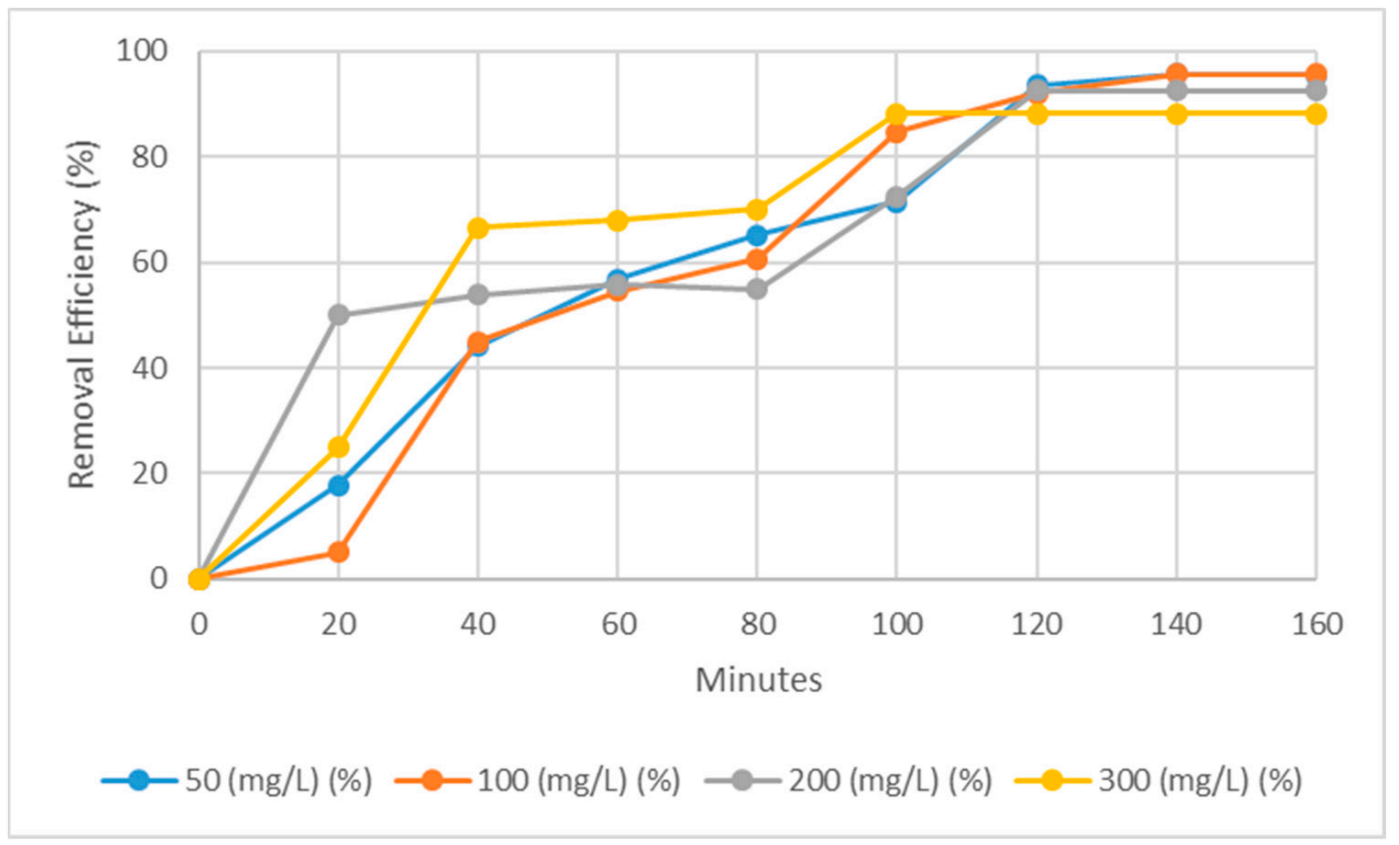

Figure 3. $(\mathrm{EC}+\mathrm{Fe})$ removal efficiency. 
In the percentage removal of $\mathrm{Cr}(\mathrm{VI})$, the saturation of the biomass of $(\mathrm{EC})$ removed only $40 \%$ of the initial concentrations of $300 \mathrm{mg} / \mathrm{L}$. However, with the initial $\mathrm{Cr}$ (VI) concentrations of 200,100 , and $50 \mathrm{mg} / \mathrm{L}$, significant removals of more than $80 \%$ could be observed. Figure 3 shows the removals of $(\mathrm{EC}+\mathrm{Fe})$.

Removals under initial concentrations of $(\mathrm{EC}+\mathrm{Fe})$ were significant; at minute 80 , the initial concentrations of 50 and $100 \mathrm{mg} / \mathrm{L}$ were already above $60 \%$ removed, showing that removal and subsequent saturation is much greater than the vegetable cellulose of (EC), removing around $96 \%$ of the initial $\mathrm{Cr}(\mathrm{VI})$ in all concentrations.

\section{Adsorption Isotherms}

There were four different starting points-initial concentrations of 50, 100, 200, and $300 \mathrm{mg} / \mathrm{L}$ of $\mathrm{Cr}(\mathrm{VI})$. Each process yielded four final concentrations $\left(C_{e}\right)$, which could be defined as the equilibrium concentration, and four final capacities $(q)$, which could be called equilibrium capacity; with these clear parameters the Langmuir isotherms will be obtained [33,34].

Langmuir adsorption isotherms are shown in Figures 4 and 5, the graph of $\left(C_{e} / q\right)$. $C_{e}$ for $\mathrm{Cr}(\mathrm{VI})$ adsorption, representing the Langmuir equation; with this graph it was possible to obtain the maximum capacity $(q)$ of adsorption of these biomasses.

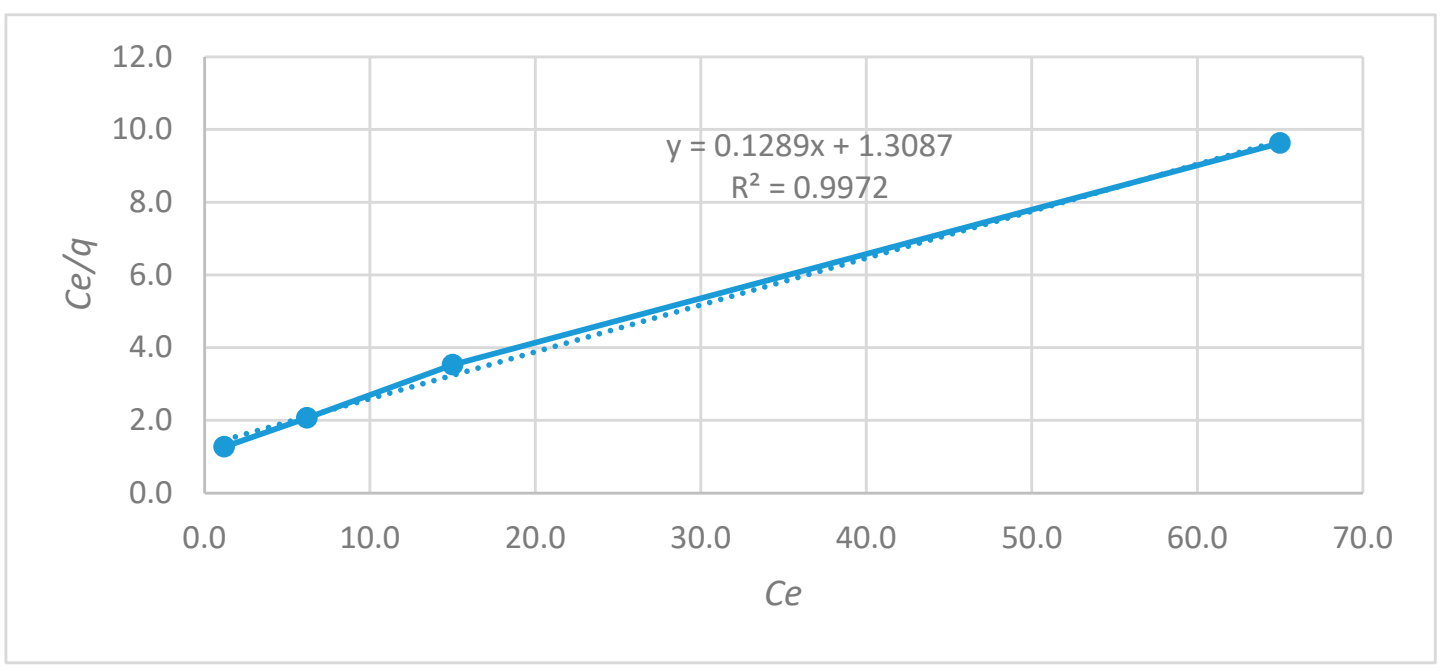

Figure 4. Langmuir isotherm EC.

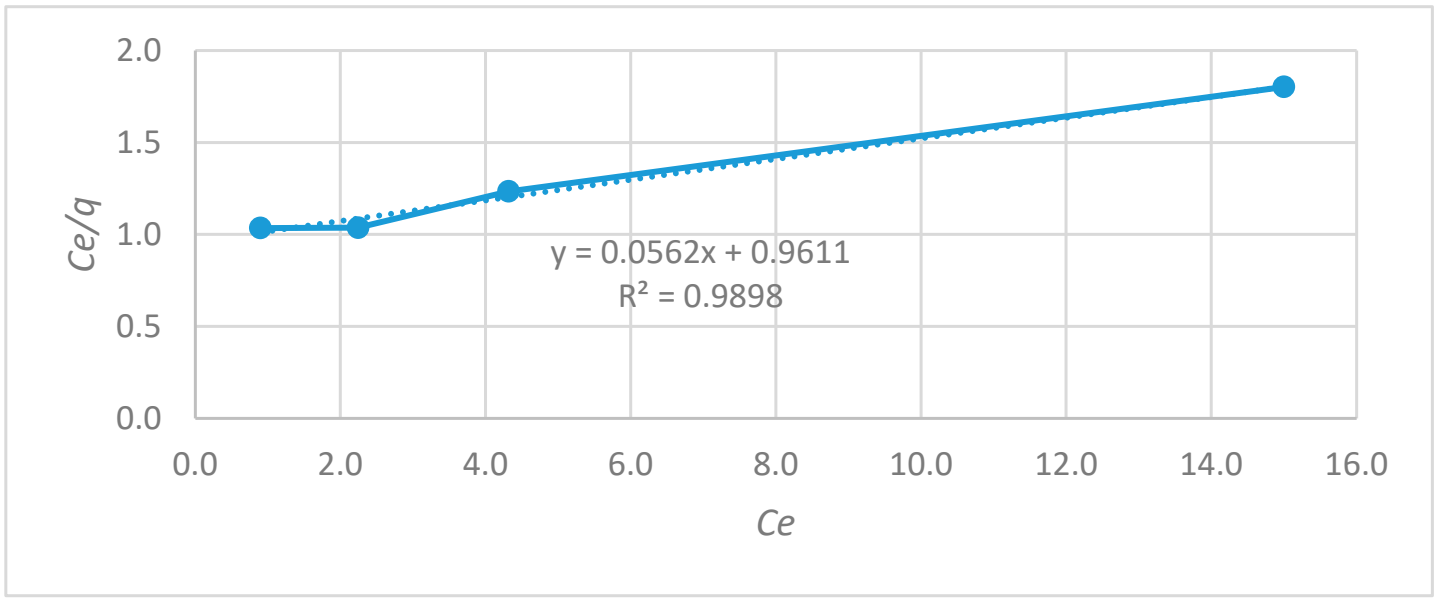

Figure 5. Langmuir isotherms $(\mathrm{EC}+\mathrm{Fe})$. 
A representative fit of $0.992 R^{2}$ can be observed. Taking as reference the Langmuir equation, which is:

$$
\frac{C_{e}}{q_{e}}=\frac{1}{q_{m}} C_{e}+\left(\frac{1}{q_{m} B}\right)
$$

The maximum capacity variable $\left(q_{m}\right)$ was obtained by solving for the expression observed in Figure $4 \mathrm{y}=0.128 \mathrm{x}+1.3087$. The expression $0.128 \mathrm{x}$ is akin to $1 /\left(q_{m}\right) C_{e}$, where the maximum capacity $\left(q_{m}\right)$ of the biomass of $(\mathrm{EC})$ obtained the design parameter of maximum $\mathrm{Cr}(\mathrm{VI})$ retention capacity by part of the biomass of (EC) of $7.66 \mathrm{mg} / \mathrm{L}$; similar results were seen in the experiments reported by [8,34-36], where they used biomass of (EC) without modification. Figure 5 shows the Langmuir isotherms of the biomass experiment $(\mathrm{EC}+\mathrm{Fe})$.

Observing Figure 5, the maximum capacity was obtained from the equation of the line, clearing 0.0586 , and the maximum capacity $\left(q_{m}\right)$ of the cellulose of $(\mathrm{EC}+\mathrm{Fe})$ was obtained $-17 \mathrm{mg} / \mathrm{g}$; similar results were seen in the reported experiments [20].

Comparing (EC) and (EC $+\mathrm{Fe})$, it can be concluded that the latter has a capacity almost 2.5 times greater $(\mathrm{EC})$ as iron oxidizes the organic matter, creating more active groups favoring chemisorption.

The adsorption capacities obtained of $(\mathrm{EC}+\mathrm{Fe})$ and $(\mathrm{EC})$ were using for the followed process of design of the biofilters.

\subsection{Continuous Experimentation}

For the development of the biofilter, equation (10) was used to find the biomass ideal in the removal of $\mathrm{Cr}(\mathrm{VI})$.

$$
m=\frac{20\left(\frac{\mathrm{ml}}{\mathrm{min}}\right) * 0.5\left(\frac{\mathrm{mg}}{\mathrm{ml}}\right) * 92(\mathrm{~min})}{17\left(\frac{\mathrm{mg}}{\mathrm{g}}\right)}-\frac{0.5\left(\frac{\mathrm{mg}}{\mathrm{ml}}\right) * 0.5 * 250(\mathrm{ml})}{17\left(\frac{\mathrm{mg}}{\mathrm{g}}\right)}
$$

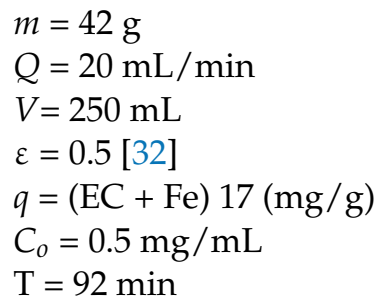

The biomass used in the biofilter was $42 \mathrm{~g}$ of $(\mathrm{EC}+\mathrm{Fe})$. The theoretical breakthrough curve for the biomass of (EC $+\mathrm{Fe}$ ) was $92 \mathrm{~min}$, and the adsorption capacity found in the batch helped to find the required biomass along with the design flow. This value represents the possible capacity that the biomass of $(\mathrm{EC}+\mathrm{Fe}$ ) will have to initially support 500 or $0.5 \mathrm{mg} / \mathrm{mL}$.

For the biomass of (EC), it was calculated similar to $(\mathrm{EC}+\mathrm{Fe})$, but with an adsorption capacity of $7.66 \mathrm{mg} / \mathrm{g}$, and the terms were replaced in the equation:

$$
m=\frac{20\left(\frac{\mathrm{ml}}{\mathrm{min}}\right) * 0.5\left(\frac{\mathrm{mg}}{\mathrm{ml}}\right) * 55(\mathrm{~min})}{7.66\left(\frac{\mathrm{mg}}{\mathrm{g}}\right)}-\frac{0.5\left(\frac{\mathrm{mg}}{\mathrm{ml}}\right) * 0.5 * 250(\mathrm{ml})}{7.66\left(\frac{\mathrm{mg}}{\mathrm{g}}\right)}
$$

$m=64 \mathrm{~g}$

$Q=20 \mathrm{~mL} / \mathrm{min}$

$V=250 \mathrm{~mL}$

$\varepsilon b=0.5[32]$

$q=(\mathrm{EC}) 7.66 \mathrm{mg} / \mathrm{g}$

$C_{0}=0.5 \mathrm{mg} / \mathrm{mL}$

$\mathrm{T}=55 \mathrm{~min}$

The biomass used in the biofilter was $64 \mathrm{~g}$-biomass of (EC) to incorporate in the biofilter. The theoretical breakthrough curve for the biomass of (EC) is $55 \mathrm{~min}$; due to it is 
greater capacity, the biomass of $(\mathrm{EC}+\mathrm{Fe})$ can last longer before saturation. For this reason, a higher biomass of (EC) was required. After determining how much biomass was needed and establishing the assembly conditions, the biofilter was developed with the biomasses.

\subsection{Design and Construction of the Biofilter at the Pilot Scale}

The biofilter was built with plastic (PET) bottles, where two compartments of $32 \mathrm{~g}$ were designed for the biomass of (EC) and for the biomass of $(\mathrm{EC}+\mathrm{Fe}), 21 \mathrm{~g}$. It had a fine nylon mesh and consisted of two beds in series, with a diameter of $3.5 \mathrm{~cm}$ and a height of $7.5 \mathrm{~cm}$; it had orifices at the entrance to control the flow at $20 \mathrm{~mL} / \mathrm{min}$, with a $\mathrm{pH} 6$ (aqueous solutions of 0.81 ).

The density of the bed was constant, and under temperature and pressure conditions of $20^{\circ} \mathrm{C}$ and 1 bar, respectively, the system had manual flow control. Samples were taken when $100 \mathrm{~mL}$ passed through the system until the saturation of the system was completed. Then, the samples were analyzed in the atomic absorption equipment. It performance the experiment by duplicate, taking the resulting average in the figures. Figure 6 shows three photographs of the biofilter used in the process of remotions of $\mathrm{Cr}(\mathrm{VI})$.

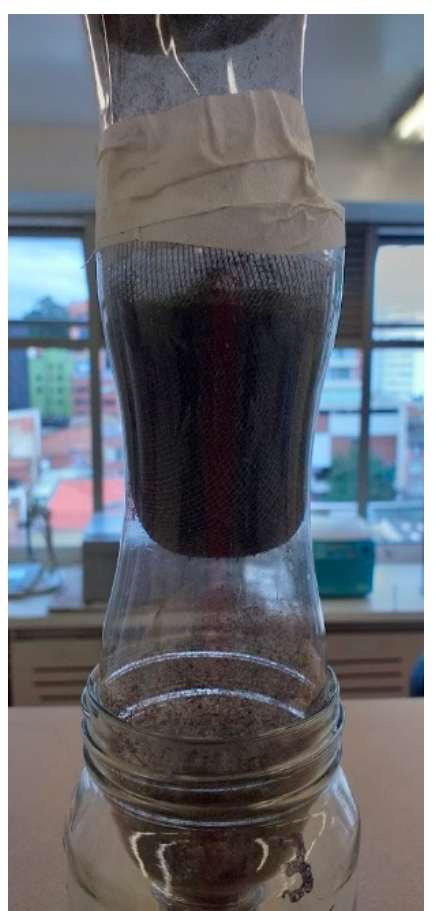

(a)

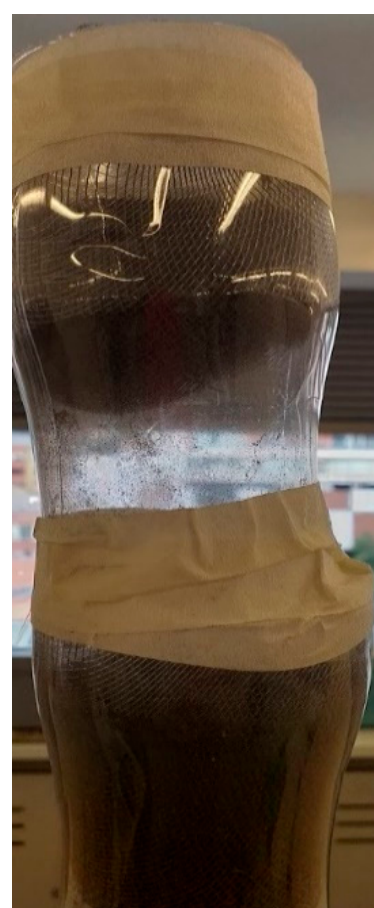

(b)

Figure 6. Biofilters used in the adsorption process: E crassipes (EC) (a); E crassipes with iron (EC + Fe) (b).

\section{Experimental Process}

Regarding the experimental process of the biofilter, the removals are shown in Figure 7 , with a biofilter with biomasses of (EC) and (EC $+\mathrm{Fe})$. At an initial $\mathrm{Cr}(\mathrm{VI})$ concentration of $500 \mathrm{mg} / \mathrm{L}$, the (EC) biofilter efficiencies were $75 \%$, with the breakthrough curve being at minute 55 when it had to treat around $300 \mathrm{~mL}$ of water. The biofilter with biomass of $(\mathrm{EC}+\mathrm{Fe})$ obtained efficiencies above $85 \%$ with initial concentrations of $500 \mathrm{mg} / \mathrm{L}$ or $\mathrm{Cr}$ (VI) and with a breakthrough curve at minute 100, treating around $400 \mathrm{~mL}$ of water. 


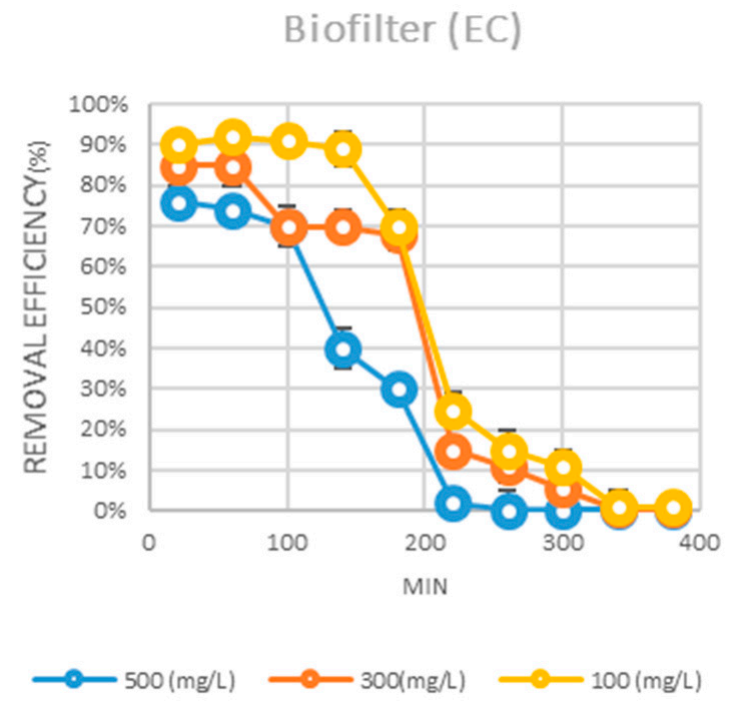

(a)

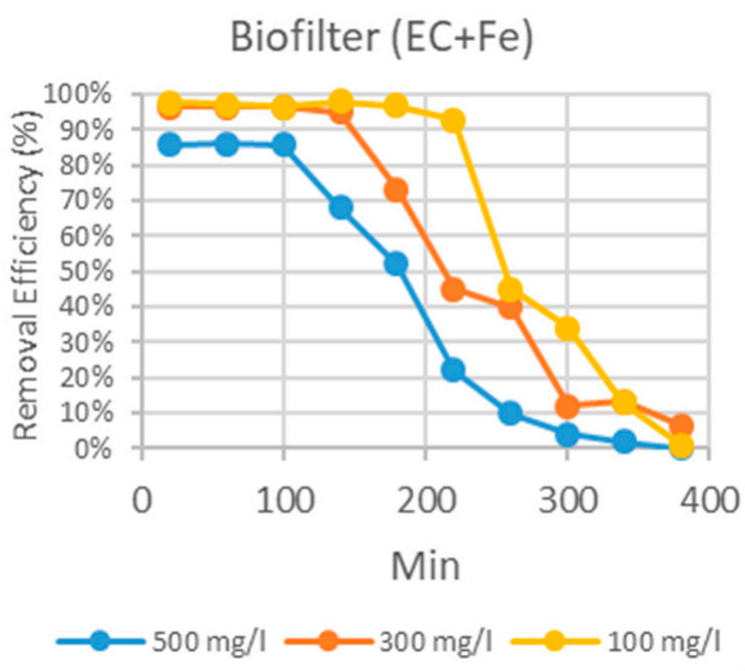

(b)

Figure 7. $(\mathrm{EC})$ and $(\mathrm{EC}+\mathrm{Fe})$ removal percentages: Biofiliters $\mathrm{EC}(\mathbf{a})$; Biofilters $\mathrm{EC}+\mathrm{Fe}(\mathbf{b})$.

Regarding the biofilter with (EC) in the treatment of initial concentrations of $300 \mathrm{mg} / \mathrm{L}$, there were efficiencies of $85 \%$ of $\mathrm{Cr}(\mathrm{VI})$, with a breakthrough curve of $100 \mathrm{~min}$, treating around $300 \mathrm{~mL}$ of water; compared to the yields of the biofilters under the same initial concentrations, the biofilter of (EC $+\mathrm{Fe}$ ) removed $95 \%$ of the $\mathrm{Cr}(\mathrm{VI})$ in the water. The breakthrough curve was at minute 100 , treating around $500 \mathrm{~mL}$ of water. The optimization of the biofilter was also evident with the initial concentration of $100 \mathrm{mg} / \mathrm{L}$, where the biomass with (EC $+\mathrm{Fe}$ ) was above $96 \%$ for the removal of $\mathrm{Cr}(\mathrm{VI})$ and the biofilter with this initial concentration was around $92 \%$ for the efficiency of this heavy metal. The treatment with iron $(\mathrm{Fe})$, optimized the efficiencies of $\mathrm{Cr}(\mathrm{VI})$, showing more treatment time and treating about $25 \%$ more water. The experiment of [37] had an efficiency of $73 \%$ of $\mathrm{Cr}$ (VI) with the (EC); in [25], this biomass also had an efficiency of $85 \%$ for $\mathrm{Cr}(\mathrm{VI})$, and in [30] the efficiency of Cd (II) was 85\% (see Table 1).

Table 1. Research with system in continuo with the different biomass.

\begin{tabular}{ccccc}
\hline Reference & Biomass & Initial Concentration mg/L & Removal Efficiency (\%) & Heavy Metal Removed \\
\hline Present article & EC & 100 & 85 & $\mathrm{Cr}(\mathrm{VI})$ \\
Present article & EC + Fe & 100 & 98 & $\mathrm{Cr}(\mathrm{VI})$ \\
{$[37]$} & EC & 100 & 73 & $\mathrm{Cr}(\mathrm{VI})$ \\
{$[25]$} & EC & 100 & 85 & $\mathrm{Cr}(\mathrm{VI})$ \\
{$[30]$} & EC & 100 & 85 & $\mathrm{Cr}(\mathrm{VI})$ \\
{$[18]$} & EC + Biochar & 200 & 95 & $\mathrm{Cd}(\mathrm{II})$ \\
{$[38]$} & Biochar & 200 & 90 & $\mathrm{Cr}(\mathrm{VI})$ \\
{$[39]$} & Algae & 200 & 90 & $\mathrm{Cu}(\mathrm{II})$ \\
{$[40]$} & Algae & 300 & 85 & $\mathrm{Cu}(\mathrm{II})$ \\
{$[41]$} & Almond shell & 100 & 95 & $\mathrm{Cr}(\mathrm{VI})$ \\
{$[42]$} & Biomass + Fe & 100 & 96 & $\mathrm{Cr}(\mathrm{VI})$ \\
{$[28]$} & Bacillus + Biochar & 100 & 95 & $\mathrm{Cr}(\mathrm{VI})$ \\
{$[42]$} & Biochar + Fe & 100 & 98 & $\mathrm{Cr}(\mathrm{VI})$ \\
\hline
\end{tabular}

Biochar removals are very interesting $[18,28,38]$, but the energy expenditure is very expensive. Algae have cellulose compositions similar to (EC) $[39,40]$, and in the development of a biofilter with this biomass, they presented interesting results when removing $\mathrm{Cu}$ (II), but (EC) is more abundant and easier to acquire than algae. The authors of [41] used almond shell, presenting removals above $95 \%$ to remove $\mathrm{Cr}$ (VI); a special combination 
designed was used in [42], where the realized composite with biochar and Fe removed around $99 \%$ of $\mathrm{Cr}(\mathrm{VI})$. The present research is based on some of the parameters used in [27]; the process in this study removed around $90 \%$ of $\mathrm{Cr}(\mathrm{VI})$ and $85 \%$ of $\mathrm{Pb}$ (II), with the biomass of $(\mathrm{EC})$.

\section{Discussion}

The biofilter with (EC) is an economic alternative for industries with effluents contaminated with heavy metals, it is also easy to develop. The pilot-scale biofilter for treatment of almost $10 \mathrm{~L}$ of water with $\mathrm{Cr}(\mathrm{VI})$ would cost around USD $\$ 10[1,27]$. The iron-modified biofilter can be used in industry where the contamination of its effluents is very high. Although this biofilter is more difficult to develop, it can treat more complex pollutants. The pilot-scale biofilter, for treatment of almost $10 \mathrm{~L}$, costs about USD \$16 [1,23].

Equation (10) could be used for different treatment processes due to the adjustments to caudal, volume, mass, breakthrough curve, and capacities of remotions and relating the density of the particle to the density of the bed. With this equation, a system of treatment can be designed with the aim of removing different contaminates, as Equation (10) is not limited to removing the $\mathrm{Cr}(\mathrm{VI})$ alone and can also adjust to the limit of dumping.

$\mathrm{Cr}$ (VI) saturated biomass was finally disposed of as a hazardous waste. It is recommended to continue with sustainable projects for the production of biofuels with this material, taking advantage of its cellulose.

\section{Conclusions}

In the batch experiment carried out at the laboratory scale to determine the capacity parameter of the biomasses of $(\mathrm{EC})$ and $(\mathrm{EC}+\mathrm{Fe})$, it was concluded that these biomasses are $7.66 \mathrm{mg} / \mathrm{g}$ and $17 \mathrm{mg} / \mathrm{g}$, respectively. A mass balance was carried out with the goal of finding the equations ideal for design of systems at the pilot scale, determining the mass adequacy of $(\mathrm{EC})$ and $(\mathrm{EC}+\mathrm{Fe})$ for the treatment of $\mathrm{Cr}(\mathrm{VI})$. The masses suggested that for a maximum $\mathrm{Cr}(\mathrm{VI})$ concentration of $500 \mathrm{mg} / \mathrm{L}, 42 \mathrm{~g}$ together with a flow rate of $10 \mathrm{~mL} / \mathrm{min}$ for the biomass of (EC $+\mathrm{Fe}$ ) was required, eliminating approximately $90 \%$ of the $\mathrm{Cr}(\mathrm{VI})$. For the biomass of $(\mathrm{EC})$, the model suggested that, for the treatment of maximum $\mathrm{Cr}(\mathrm{VI})$ with a concentration of $500 \mathrm{mg} / \mathrm{L}$, the biomass should be $64 \mathrm{~g}$ together with a flow rate of $10 \mathrm{~mL} / \mathrm{min}$, removing around $80 \%$ of the $\mathrm{Cr}(\mathrm{VI})$ in a liter of water. Both biofilters are able to adapt to the conditions of the effluents of industries-for example, the biofilter with biomass of $(\mathrm{EC}+\mathrm{Fe})$ can treat water with high concentrations of $\mathrm{Cr}(\mathrm{VI})$ for above $500 \mathrm{mg} / \mathrm{L}$ and the biofilter with (EC) could treat waters with concentrations of under $500 \mathrm{mg} / \mathrm{L}$ of $\mathrm{Cr}(\mathrm{VI})$.

Funding: The university "Los Libertadores" is the entity that contributed to the development of this article.

Institutional Review Board Statement: Not applicable.

Informed Consent Statement: Not applicable.

Data Availability Statement: The data presented in this study is available on request from the author.

Conflicts of Interest: The author declares no conflict of interest.

\section{References}

1. Sayago, U.F.C.; Castro, Y.P.; Rivera, L.R.C.; Mariaca, A.G. Estimation of equilibrium times and maximum capacity of adsorption of heavy metals by E. crassipes. Environ. Monit. Assess. 2020, 192, 141. [CrossRef]

2. Zhao, L.; Cao, X.; Zheng, W.; Scott, J.W.; Sharma, B.K.; Chen, X. Copyrolysis of biomass with phosphate fertilizers to improve biochar carbon retention, slow nutrient release, and stabilize heavy metals in soil. ACS Sustain. Chem. Eng. 2016, 4, 1630-1636. [CrossRef]

3. Sidhu, G.P.S. Heavy metal toxicity in soils: Sources, remediation technologies and challenges. Adv. Plants Agric. Res. 2016, 5, 1-2.

4. Corral-Bobadilla, M.; González-Marcos, A.; Vergara-González, E.P.; Alba-Elías, F. Bioremediation of waste water to remove heavy metals using the spent mushroom substrate of Agaricus bisporus. Water 2019, 11, 454. [CrossRef] 
5. Corral Bobadilla, M.; Lostado Lorza, R.; Somovilla Gomez, F.; Escribano Garcia, R. Adsorptive of Nickel in wastewater by olive stone waste: Optimization through multi-response surface methodology using desirability functions. Water 2020, 12, 1320. [CrossRef]

6. Corral-Bobadilla, M.; González-Marcos, A.; Alba-Elías, F.; de Santo Domingo, E.D. Valorization of bio-waste for the removal of aluminum from industrial wastewater. J. Clean. Prod. 2020, 264, 121608. [CrossRef]

7. Carreño-Sayago, U.F. Development of microspheres using water hyacinth (Eichhornia crassipes) for treatment of contaminated water with Cr (VI). Environ. Dev. Sustain. 2021, 23, 4735-4746. [CrossRef]

8. El-Zawahry, M.M.; Abdelghaffar, F.; Abdelghaffar, R.A.; Hassabo, A.G. Equilibrium and kinetic models on the adsorption of Reactive Black 5 from aqueous solution using Eichhornia crassipes/chitosan composite. Carbohydr. Polym. 2016, 136, 507-515. [CrossRef] [PubMed]

9. Li, C.; Ma, H.; Venkateswaran, S.; Hsiao, B.S. Highly efficient and sustainable carboxylated cellulose filters for removal of cationic dyes/heavy metals ions. Chem. Eng. J. 2020, 389, 123458. [CrossRef]

10. Garba, Z.N.; Lawan, I.; Zhou, W.; Zhang, M.; Wang, L.; Yuan, Z. Microcrystalline cellulose (MCC) based materials as emerging adsorbents for the removal of dyes and heavy metals-A review. Sci. Total Environ. 2020, 717, 135070. [CrossRef] [PubMed]

11. Yao, M.; Wang, Z.; Liu, Y.; Yang, G.; Chen, J. Preparation of dialdehyde cellulose graftead graphene oxide composite and its adsorption behavior for heavy metals from aqueous solution. Carbohydr. Polym. 2019, 212, 345-351. [CrossRef]

12. Emam, A.A.; Faraha, S.A.A.; Kamal, F.H.; Gamal, A.M.; Basseem, M. Modification and characterization of Nano cellulose crystalline from Eichhornia Crassipes using citric acid: An adsorption study. Carbohydr. Polym. 2020, 33, 116202. [CrossRef] [PubMed]

13. Yin, T.; Zhang, X.; Liu, X.; Li, B.; Wang, C. Cellulose-based aerogel from Eichhornia crassipes as an oil superabsorbent. RSC Adv. 2016, 6, 98563-98570. [CrossRef]

14. Pratama, J.H.; Amalia, A.; Rohmah, R.L.; Saraswati, T.E. The extraction of cellulose powder of water hyacinth (Eichhornia crassipes) as reinforcing agents in bioplastic. In Proceedings of the AIP Publishing Conference, Zurich, Switzerland; AIP Publishing LLC: Melville, NY, USA, 2019; Volume 2219, p. 100003.

15. Feng, W.; Xiao, K.; Zhou, W.; Zhu, D.; Zhou, Y.; Yuan, Y.; Xiao, N.; Wan, X.; Hua, Y.; Zhao, J. Analysis of utilization technologies for Eichhornia crassipes biomass harvested after restoration of wastewater. Bioresour. Technol. 2017, 223, 287-295. [CrossRef] [PubMed]

16. Sayago, U.F.C. Design of a sustainable development process between phytoremediation and production of bioethanol with Eichhornia crassipes. Environ. Monit. Assess. 2019, 191, 221. [CrossRef] [PubMed]

17. Módenes, A.N.; Espinoza-Quiñones, F.R.; Trigueros, D.E.; Lavarda, F.L.; Colombo, A.; Mora, N.D. Kinetic and equilibrium adsorption of $\mathrm{Cu}$ (II) and Cd (II) ions on Eichhornia crassipes in single and binary systems. Chem. Eng. J. 2017, 168, 44-51. [CrossRef]

18. Chen, L.; Li, F.; Wei, Y.; Li, G.; Shen, K.; He, H.J. High cadmium adsorption on nanoscale zero-valent iron coated Eichhornia crassipes biochar. Environ. Chem. Lett. 2019, 17, 589-594. [CrossRef]

19. Cao, X.; Huang, Y.; Tang, C.; Wang, J.; Jonson, D.; Fang, Y. Preliminary study on the electrocatalytic performance of an iron biochar catalyst prepared from iron-enriched plants. J. Environ. Sci. 2020, 88, 81-89. [CrossRef]

20. Pereira, A.R.; Soares, L.C.; Teodoro, F.S.; Elias, M.M.C.; Ferreira, G.M.D.; Savedra, R.M.L.; Siqueira, M.F.; Martineau-Corcos, C.; da Silva, L.H.M.; Prim, D.; et al. Aminated cellulose as a versatile adsorbent for batch removal of As (V) and Cu (II) from mono-and multicomponent aqueous solutions. J. Colloid Interface Sci. 2020, 576, 55-99. [CrossRef]

21. Rápó, E.; Posta, K.; Csavdári, A.; Vincze, B.É.; Mara, G.; Kovács, G.; Haddidi, I.; Tonk, S. Performance Comparison of Eichhornia crassipes and Salvinia natans on Azo-Dye (Eriochrome Black T) Phytoremediation. Crystals 2020, 10, 565. [CrossRef]

22. Rigueto, C.V.T.; Piccin, J.S.; Dettmer, A.; Rosseto, M.; Dotto, G.L.; de Oliveira Schmitz, A.P.; Perondi, D.; de Freitas, T.S.M.; Loss, R.A.; Geraldi, C.A.Q. Water hyacinth (Eichhornia crassipes) roots, an amazon natural waste, as an alternative biosorbent to uptake a reactive textile dye from aqueous solutions. Ecol. Eng. 2020, 150, 105817. [CrossRef]

23. Lin, S.; Yang, H.; Na, Z.; Lin, K. A novel biodegradable arsenic adsorbent by immobilization of iron oxyhydroxide (FeOOH) on the root powder of long-root Eichhornia crassipes. Chemosphere 2018, 192, 258-266. [CrossRef]

24. Baldikova, E.; Pospiskova, K.; Ladakis, D.; Kookos, I.K.; Koutinas, A.A.; Safarikova, M.; Safarik, I. Magnetically modified bacterial cellulose: A promising carrier for immobilization of affinity ligands, enzymes, and cells. Mat. Sci. Eng. 2017, 71, $214-221$. [CrossRef] [PubMed]

25. Jin, X.; Xiang, Z.; Liu, Q.; Chen, Y.; Lu, F. Polyethyleneimine-bacterial cellulose bioadsorbent for effective removal of copper and lead ions from aqueous solution. Bioresour. Technol. 2017, 244, 844-849. [CrossRef]

26. Mpouras, T.; Polydera, A.; Dermatas, D.; Verdone, N.; Vilardi, G. Multi wall carbon nanotubes application for treatment of Cr (VI)-contaminated groundwater; Modeling of batch \& column experiments. Chemosphere 2021, 269, 128749.

27. Sarkar, M.; Rahman, A.K.M.L.; Bhoumik, N.C. Remediation of chromium and copper on water hyacinth (E. crassipes) shoot powder. Water Resour. Ind. 2017, 17, 1-6. [CrossRef]

28. Sukumar, C.; Janaki, V.; Vijayaraghavan, K.; Kamala-Kannan, S.; Shanthi, K. Removal of Cr (VI) using co-immobilized activated carbon and Bacillus subtilis: Fixed-bed column study. Clean Technol. Environ. Policy 2017, 19, 251-258. [CrossRef]

29. Vilardi, G.; Rodriguez-Rodriguez, J.; Ochando-Pulido, J.M.; Di Palma, L.; Ver-done, N. Fixed-bed reactor scale-up and modelling for $\mathrm{Cr}$ (VI) removal using nano iron-based coated biomass as packing material. Chem. Eng. J. 2018, 361, 990-998. [CrossRef] 
30. Adornado, A.P.; Soriano, A.N.; Orfiana, O.N.; Pangon, M.B.J.; Nieva, A.D. Simulated biosorption of Cd (II) and Cu (II) in single and binary metal systems by water hyacinth (Eichhornia crassipes) using Aspen adsorption. ASEAN J. Chem. Eng. 2017, 16, 21-43. [CrossRef]

31. Worch, E. Adsorption Technology in Water Treatment: Fundamentals, Processes, and Modeling; Walter de Gruyter: Berlin, Germany, 2012; p. 344.

32. Iváñez, M. Diseño de un Sistema de Adsorción para la Eliminación de Fenol Presente en Disolución Acuosa. Ph.D. Dissertation, Universitat Politècnica de València, Valencia, Spain, 2017.

33. Qiao, L.; Li, S.; Li, Y.; Liu, Y.; Du, K. Fabrication of superporous cellulose beads via enhanced inner cross-linked linkages for high efficient adsorption of heavy metal ions. J. Clean. Prod. 2020, 253, 120017. [CrossRef]

34. Xiao, Y.; Liu, Y.; Wang, X.; Li, M.; Lei, H.; Xu, H. Cellulose nanocrystals prepared from wheat bran: Characterization and cytotoxicity assessment. Int. J. Biol. Macromol. 2019, 140, 225-233. [CrossRef]

35. Li, X.; Liu, S.; Na, Z.; Lu, D.; y Liu, Z. La adsorción, la concentración, y la recuperación de iones de metales pesados acuosas con el polvo de raíz de Eichhornia crassipes. Ingeniería Ecológica 2013, 60, 160-166.

36. Yi, Z.J.; Yao, J.; Chen, H.L.; Wang, F.; Yuan, Z.M.; Liu, X. Uranium biosorption from aqueous solution onto Eichhornia crassipes. J. Environ. Radioact. 2016, 154, 43-51. [CrossRef]

37. Tejada-Tovar, C.; Paz, I.; Acevedo-Correa, D.; Espinosa-Fortich, M.; López-Badel, C. Adsorption of chrome (VI) and mercury (II) in solution using hyacinth (Eichhornia crassipes). Biotecnología en el Sector Agropecuario y Agroindustrial 2017, 19, 54-65. [CrossRef]

38. Zhang, Y.P.; Adi, V.S.K.; Huang, H.L.; Lin, H.P.; Huang, Z.H. Adsorption of metal ions with biochars derived from biomass wastes in a fixed column: Adsorption isotherm and process simulation. J. Ind. Eng. Chem. 2020, 76, 240-244. [CrossRef]

39. de Freitas, G.R.; Vieira, M.G.A.; da Silva, M.G.C. Batch and fixed bed biosorption of copper by acidified algae waste biomass. Ind. Eng. Chem. Res. 2018, 57, 11767-11777. [CrossRef]

40. Barquilha, C.E.R.; Cossich, E.S.; Tavares, C.R.G.; Silva, E.A. Biosorption of nickel (II) and copper (II) ions in batch and fixed-bed columns by free and immobilized marine algae Sargassum sp. J. Clean. Prod. 2017, 150, 58-64. [CrossRef]

41. Yahya, M.D.; Abubakar, H.; Obayomi, K.S.; Iyaka, Y.A.; Suleiman, B. Simultaneous and continuous biosorption of Cr and Cu (II) ions from industrial tannery effluent using almond shell in a fixed bed column. RINENG 2020, 6, 100113. [CrossRef]

42. Song, X.; Zhang, Y.; Cao, N.; Sun, D.; Zhang, Z.; Wang, Y.; Wen, Y.; Yang, Y.; Lyu, T. Sustainable Chromium (VI) Removal from Contaminated Groundwater Using Nano-Magnetite-Modified Biochar via Rapid Microwave Synthesis. Molecules 2021, $26,103$. [CrossRef] 